\title{
Pre-harvest desiccation in biomass sorghum with herbicides ${ }^{1}$
}

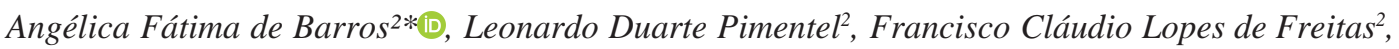 \\ Paulo Roberto Cecon ${ }^{3}$, Adriano Cirino Tomaz ${ }^{2}$, Evandro Marcos Biesdorf ${ }^{2}$
}

10.1590/0034-737X202067050001

\begin{abstract}
The purpose of this study was to assess the effect of different herbicide treatments on moisture removal and calorific power of biomass sorghum for co-generation of electric energy through burning. The experiment was conducted in randomized complete block design with four replicates per treatment and a $6 \times 4$ factorial scheme (six herbicide treatments $\mathrm{x}$ four intervals between spraying and harvesting). The herbicide treatments were: two different doses of glyphosate $\left(1.92 \mathrm{~kg}\right.$ a.i. $\mathrm{ha}^{-1}$ and $3.84 \mathrm{Kg}$ a.i. ha $\left.{ }^{-1}\right)$, paraquat $\left(0.4 \mathrm{Kg}_{\text {a.i. }} \mathrm{ha}^{-1}\right)$, a commercial mixture of paraquat + diuron $(0.6+0.3 \mathrm{Kg}$ a.i. ha $\left.{ }^{-1}\right)$, glufosinate-ammonium $\left(0.8 \mathrm{Kg}_{\text {a.i. }} \mathrm{ha}^{-1}\right)$ and control (unsprayed). The intervals between spraying and harvesting assessed were 7, 14, 21 and 28 days after desiccation (DAD). It was assessed: the number of leaves per plant, moisture content of leaves, panicles, culm and whole ground plants and Superior Calorific Power (SCP). The herbicides paraquat and paraquat + diuron promotes defoliation, after 14 DAD. Glyphosate, paraquat, paraquat + diuron and glufosinateammonium reduce leaf and panicle moisture, despite only glyphosate reduces moisture in the culm. The herbicides do not affect the SCP of biomass sorghum. Therefore, the herbicides, especially glyphosate, have high potential for preharvest desiccation in biomass sorghum.
\end{abstract}

Keywords: Sorghum bicolor; glyphosate; paraquat; diuron; glufosinate-ammonium.

\section{INTRODUCTION}

The demand for renewable fuels has increased the interest in crops designated for biodiesel and second generation ethanol production (Alvim et al., 2014). This also contributes to the expansion of the energy cogeneration market, resulting from the burning of biomass for electricity production. To meet this worldwide demand, biomass production must be consistent, continuous and with high quality of raw material (Alonso et al., 2017). Thus, lignocellulosic biomass from various sources has been used, such as crop residues, sugarcane bagasse and maize straw, as well as trees and grasses (Guerriero et al., 2016). In this context, biomass sorghum is capable of expanding the cogeneration of electricity by the sugarcane industry (Liu et al., 2017) as it has a high fiber content, short production cycle (six months), adaptation to various climate and soil conditions and lower water requirements than sugarcane and maize (Galina et al., 2018).
Moisture is one of the factors that most influences the energy yield of the crop. Materials harvested with moisture above $70 \%$ reduce industrial yield due to the energy expended for water evaporation during raw burning (Colauzzi et al., 2018). Thus, growers expect natural drying of plants in the field to values close to $60 \%$. Although, according to Moura et al. (2015) the moisture content of the raw material at harvest for burning should be close to $50 \%$. However, depending on the climatic conditions and the cultivar, the decrease in moisture content may take more than 40 days after full flowering (May et al., 2015). This waiting time reduce calorific power and increase the risks of losses caused by lodging, plant breakdown and diseases (Teixeira, 2017). Thus, pre-harvest desiccation with herbicides enables anticipation of the harvest (Parreira et al., 2015), facilitate the work of harvesters, reduce losses resulting from exposure of plants to biotic and abiotic factors and contribute to higher quality of harvested material.

\footnotetext{
Submitted on October 23th, 2019 and accepted on August 6 $6^{\text {th }}, 2020$.

${ }^{1}$ This work is part of the doctoral thesis of the first author.

${ }^{2}$ Universidade Federal de Viçosa, Departamento de Fitotecnia, Viçosa, Minas Gerais, Brazil. agro.angelicabarros@gmail.com; leonardopimentelagro@gmail.com; francisco.freitas@ufv.br; adrianotomaz86@gmail.com; evandromarcospva@ hotmail.com

${ }^{3}$ Universidade Federal de Viçosa, Departamento de Estatística, Viçosa, Minas Gerais, Brazil. cecon@ufv.br

*Corresponding author: agro.angelicabarros@gmail.com
} 
Several herbicides have potential for pre-harvest desiccation. Paraquat is a contact herbicide which acts capturing electrons from photosynthesis and form free radicals, which promotes severe damage to photosynthetically active tissues. Gramocil@, a commercial product with the mixture of paraquat and diuron, has a higher translocation capacity with greater depth effect (Sherwani et al., 2015). Another contact product used is glufosinate-ammonium (Finale ${ }^{\circledR}$ ), which inhibits glutamine synthetase synthesis, causing ammonium accumulation, cell destruction and photosynthesis inhibition. Glyphosate, which is the most consolidated systemic herbicide on the market, inhibits the action of the enzyme 5-enolpyruvylshikimate-3phosphate synthase (EPSPs) in the synthesis route of the aromatic amino acids phenylalanine, tyrosine and tryptophan, which are precursors of products such as lignin, flavonoids and benzoic acids (Sherwani et al., 2015).

Several studies have already demonstrated the efficiency of pre-harvest desiccation in soybean (Pinto et al., 2016), beans (Silva et al., 2017), rice, canola (Zhang \& Van Vekdhuizen, 2016) and wheat (Krenchinsk et al., 2017). However, there are few research records that have evaluated the application of pre-harvest herbicides to reduce moisture in biomass crops and there are no published studies that have evaluated the effect of herbicides in desiccation of biomass sorghum (Costa et al., 2018; May et al., 2016). In this sense, the objective was to evaluate the use of herbicides in pre-harvest of biomass sorghum for moisture removal and their effect calorific power.

\section{MATERIAL AND METHODS}

The experiment was carried out from January to June 2017 in the Experimental Field "Diogo Alves de Melo," of the Federal University of Viçosa, located in Viçosa-MG ( $20^{\circ} 46$ ' $\mathrm{S}, 45^{\circ} 52^{\prime} \mathrm{W}, 650 \mathrm{~m}$ altitude). The environmental conditions during the experimental period are shown in Figure 1 . The experiment was conducted in a completely randomized design with four replicates per treatments in a $6 \times 4$ factorial scheme (six herbicide treatments $x 4$ intervals between spraying and harvesting).

The preparation of the experimental area consisted of one plowing followed by two harrows. Mechanical sowing was performed on January/16/2017, using 12 seed / linear meter, in a total area of $924 \mathrm{~m}^{2}(42 \times 22 \mathrm{~m})$. The cultivar BRS 716, available from EMBRAPA Corn and Sorghum, was used. The fertilization was performed by applying $300 \mathrm{Kg}$ $\mathrm{ha}^{-1}$ of the N-P-K $(08: 28: 16)$ during the sowing and application of $200 \mathrm{Kg} \mathrm{ha}^{-1}$ of urea ( $44 \% \mathrm{~N}$ ) after 30 days. Dicotyledonous weeds were controlled with application of $1.5 \mathrm{~L} \mathrm{ha}^{-1}$ of herbicide atrazine at 15 days after sowing. The control of monocotyledonous weeds was performed through manual weeding.
The herbicide application for sorghum chemical desiccation was carried out on May/11/2017, at 85 days after sowing, when the plants were at the phenological stage of pasty grains (Figure 2). The spraying was made with a tractor coupled bar (four tips TT 110015 flat jet) adapted to reach the height of $5 \mathrm{~m}$. Spraying speed was 3 $\mathrm{km} \mathrm{h}^{-1}$; tip flow: $0.69 \mathrm{~L} \mathrm{~min}^{-1}$; pressure: 4 bar and syrup volume: 172.5 $\mathrm{L} \mathrm{ha}^{-1}$ (Figure 2). There was a corridor between the plots, so the tractor with the sprayer could pass and thus avoiding drift that could reach the neighboring plots (Figure 2).

The herbicide treatments were: $4 \mathrm{~L} \mathrm{ha}^{-1}$ of glyphosate $\left(1.92 \mathrm{~kg}\right.$ a.i. ha $\left.{ }^{-1}\right), 8 \mathrm{~L} \mathrm{ha}^{-1}$ of glyphosate (3.84 Kg a.i. ha $\left.{ }^{-1}\right)$, $2 \mathrm{~L} \mathrm{ha}^{-1}$ of paraquat $\left(0.4 \mathrm{Kg}\right.$ a.i. ha $\left.{ }^{-1}\right), 3 \mathrm{~L} \mathrm{ha}^{-1}$ of a commercial mixture of paraquat + diuron $\left(0.6+0.3 \mathrm{Kg}\right.$ a.i. $\left.\mathrm{ha}^{-1}\right)$, glufosinate-ammonium ( $0.8 \mathrm{Kg}$ a.i. ha $\left.{ }^{-1}\right)$ and control (no application). The intervals between spraying and harvesting assessed were 7, 14, 21 and 28 days after desiccation (DAD). The experimental plots consisted of four rows of $6 \mathrm{~m}$, spaced $0.70 \mathrm{~m}$ from each other. The plants of the two outer rows of the plots were considered as border and were not used for analysis.

For the phytotechnical evaluations, all the plants from 1 linear $\mathrm{m}$ of the central row of each plot were harvest to compose one sample. The samples were collected one day before spraying to determine the initial moisture, and in 7 day intervals, totaling 5 harvests. Therefore, the last harvest was performed on June/08/2017, at 28 days after desiccation. Plants harvested in 1 linear $\mathrm{m}$ from each experimental unit were divided into two subsamples. The plants of one subsample were used for individual evaluations of number of leaves per plant and weight of fresh culm, leaves and panicle. After weighing the fresh matter, the samples were maintained in drying oven at $65^{\circ} \mathrm{C}$ until they reach a constant weight. Then, the plant parts were weighted again to determine the dry matter. Then, the weights of fresh and dry matters were used to calculate the moisture content of the plant parts by using the formula: $\left.\mathrm{MC}=\left[\left(\mathrm{m}_{1}-\mathrm{m}_{2}\right) / \mathrm{m}_{1}\right)\right] \times 100$, where $\mathrm{m}_{1}$ is the fresh weight and $\mathrm{m}_{2}$ is dry weight.

The whole plants of the other subsample were weighed and ground in a crushing machine. Then, $200 \mathrm{~g}$ of fresh matter were placed to dry in a drying oven, to determine the moisture content of the sample. After determining the moisture content of the samples, they were milled to reduce the particle size and standardize the specific surface. The mill used was the "Willye" type with $1 \mathrm{~mm}$ sieves. Subsequently, the samples were placed in kraft paper packaging, properly identified and stored.

The analyzes to determine the superior calorific power (SCP) of the samples were performed in the Panels and Wood Energy Laboratory of the Forest Engineering Department of the Federal University of Viçosa. The 
properly dried and ground samples were classified into sieves with 40 and 60 mesh meshes. The fraction between 40 and 60 Mesh was used for immediate analysis. The determination of the SCP of each sample was given by the combustion of $1 \mathrm{~g}$ of material in calorimetric pump and the $\mathrm{SCP}$ was quantified in $\mathrm{Kcal} / \mathrm{Kg}$.

The data were analyzed by Two-way analysis of variance (herbicide treatments $\mathrm{x}$ intervals between spraying and harvest). The Tukey test was used to compare the means of the qualitative variables (herbicide treatments $)(P<0.05)$. For the quantitative variables DAD, regression analysis was used. The models were chosen by the significance of the regression coefficients, using the t-test in the coefficient of determination $\mathrm{R}^{2}=$ SQ Regression / SQ Treatment) and the biological phenomenon.

\section{RESULTS AND DISCUSSION}

In the initial evaluation, before desiccation, the biomass sorghum had, in averaged, $4 \mathrm{~m}$ in height, 15 leaves per plant, sample moisture content (composed of leaves, culm and panicle) of $74.22 \%$ (Figure 3D) and calorific value higher than $4390 \mathrm{Kcal}$ / Kg. According to May et al. (2015), the moisture of the biomass sorghum plants at the panicle emission development stage is nearly $75 \%$ and at this stage, the crop yield is already defined.

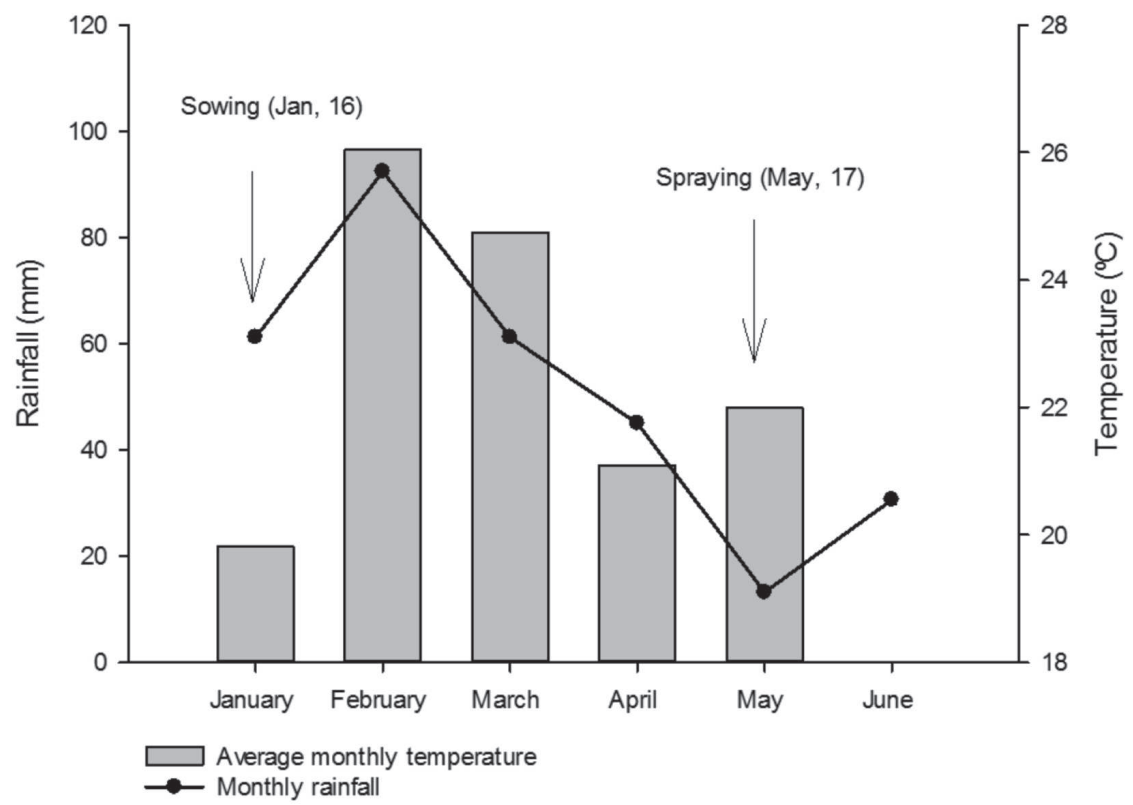

Source: Boletim Metereológico/ UFV, 2017.

Figure 1: Monthly rainfall and average temperature in Viçosa, MG, during the period of the experiment (2017).

A)

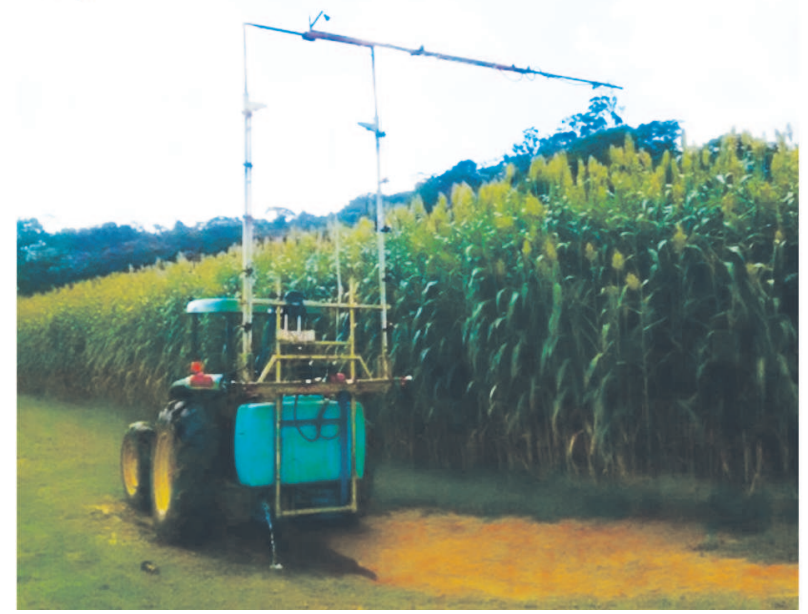

B)

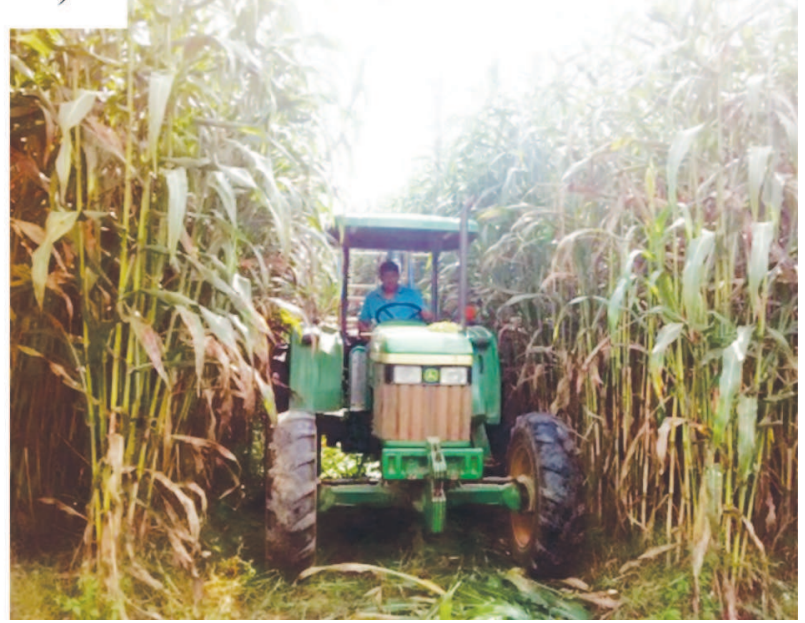

Figure 2: A) Tractor with bar adapted for the application of herbicides in biomass sorghum B) Central corridor for tractor transit and herbicide application. 
Up to 14 days after desiccation (DAD) there was no significant difference between treatments for the number of leaves per plant (Figure 3A). However, at 21 and 28 $\mathrm{DAD}$, the plants sprayed with paraquat and paraquat + diuron presented defoliation. In the last evaluation (28 DAD), the plants sprayed with glufosinate-ammonium had 13 leaves on average, while the plants sprayed with paraquat and paraquat + diuron had lost on average three leaves per plant. As leaves also compose the raw material for burning process in energy production, defoliation is considered undesirable.

In general, the leaf moisture content in all herbicide treatments was lower than control (without application), during all period of the experiment. The lowest leaf moisture content at $7 \mathrm{DAD}$ was observed for paraquat and paraquat + diuron. At 14 and 21 DAD, the both doses of glyphosate,

\begin{tabular}{|ll|}
\hline Control (without desiccation) & Paraquat $(0,4 \mathrm{~kg} / \mathrm{ha})$ \\
Glyphosate $(1,92 \mathrm{~kg} / \mathrm{ha})$ & Paraquat + Diuron $(0,6+0,3 \mathrm{~kg} / \mathrm{ha})$ \\
Glyphosate $(3,84 \mathrm{~kg} / \mathrm{ha})$ & Glufosinate ammonium $(0,8 \mathrm{~kg} / \mathrm{ha})$ \\
\hline
\end{tabular}

A)

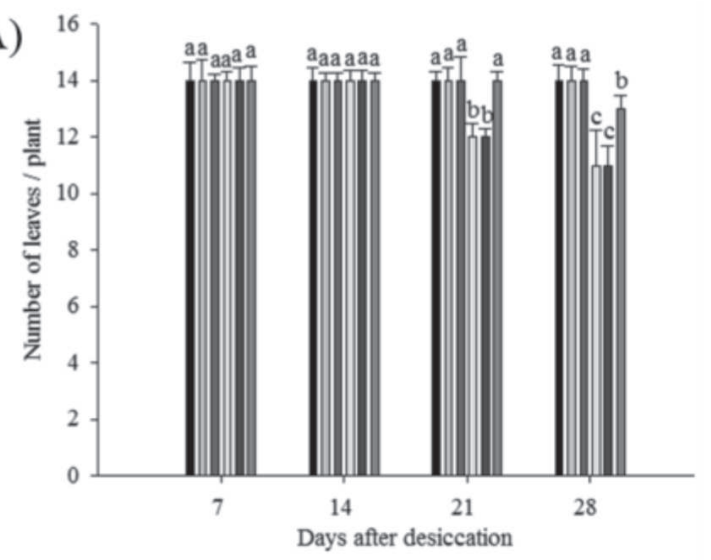

C)

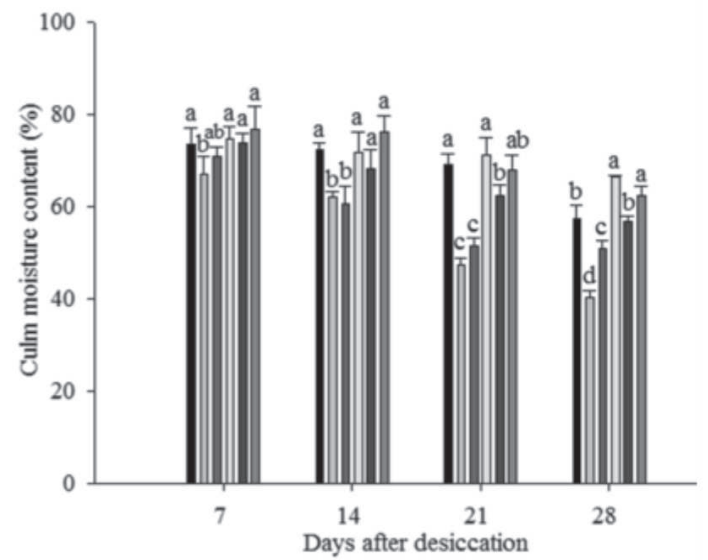

E)

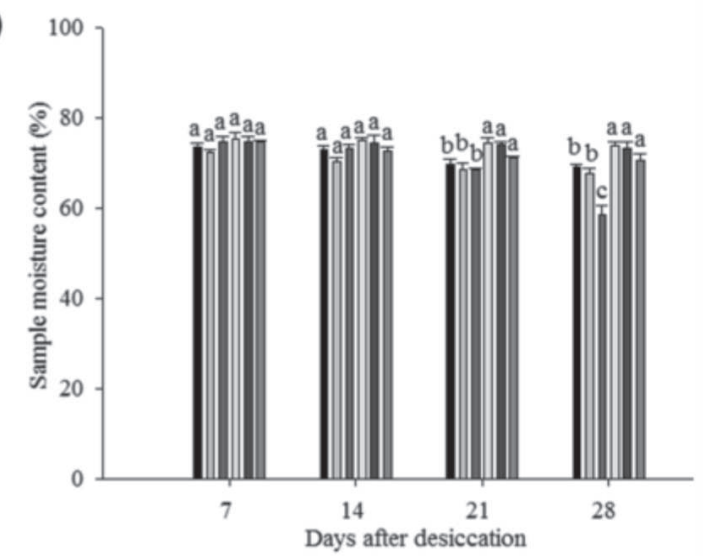

B)

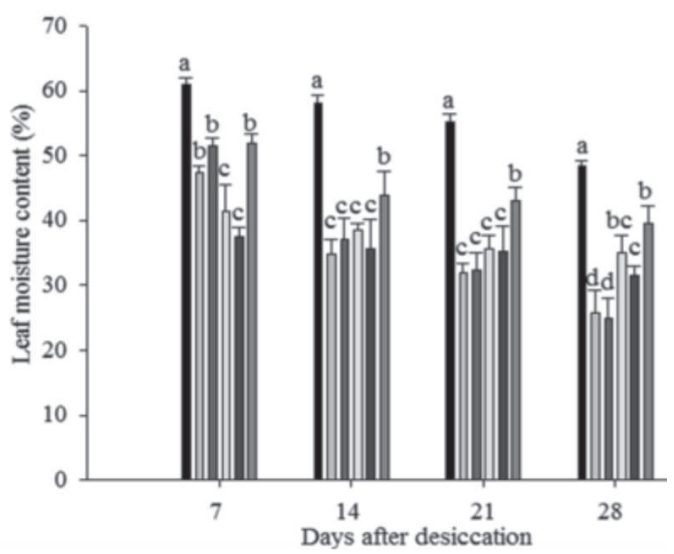

D)

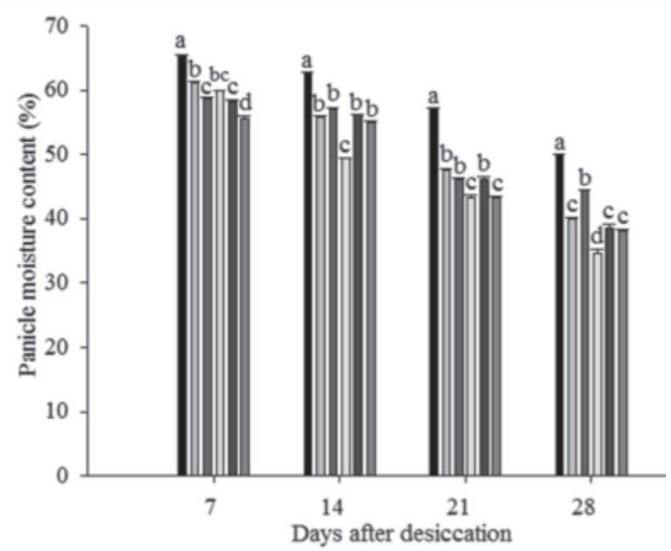

F)

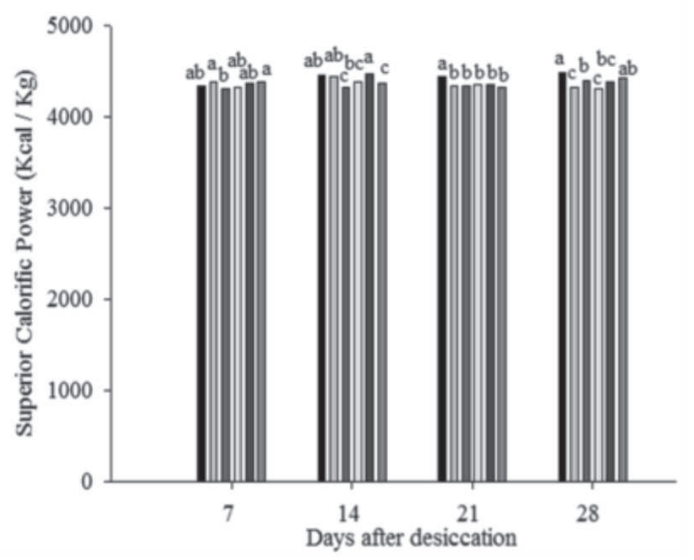

Figure 3: (A) Number of leaves per plant, (B) Leaf moisture content (\%), (C) Culm moisture content (\%), (D) Panicle moisture content (\%), (E) Sample moisture content (\%) and Superior Calorific Power (SCP) (Kcal / Kg) of biomass sorghum plants at 7, 14, 21 and 28 days after spraying with glyphosate $\left(1.92 \mathrm{~kg}\right.$ a.i. $\mathrm{ha}^{-1}$ and $3.84 \mathrm{Kg}$ a.i. ha $\left.{ }^{-1}\right)$, paraquat, paraquat + diuron, glufosinateammonium and control (without spraying). 
paraquat and paraquat + diuron had the lowest leaf moisture contents (approximately 35\%). However, at 28 $\mathrm{DAD}$, the both doses of glyphosate had the lowest leaf moisture contents (Figure 3B).

The culm moisture content at 7 DAD did not differ among treatments, except for the lowest dose of glyphosate, which had the lowest value. However, from 14 to $28 \mathrm{DAD}$, the lowest culm moisture contents were observed in plants treated with both doses of glyphosate. Although, at $28 \mathrm{DAD}$, the lowest dose of glyphosate had the culm moisture content significantly lower than the highest dose of glyphosate (Figure 3C).

In general, the panicle moisture content in all herbicide treatments was lower than in control (Figure 3D). At 7 $\mathrm{DAD}$, the treatment with lowest value was glufosinateammonium. However, at 14 DAD, paraquat had the lowest panicle moisture content, around $50 \%$. At 21 DAD, paraquat and paraquat + diuron had the lowest panicle moisture contents. At $28 \mathrm{DAD}$, paraquat had the lowest value while the lowest dose of glyphosate, paraquat + diuron and glufosinate-ammonium showed panicle moisture content close to $40 \%$, with no statistical difference among them (Figure 3D).

Up to 14 DAD the moisture content of the sample composed of leaf, culm and panicle was above $70 \%$, with no significant differences among treatments, including control (without application) (Figure 3E). Although, at 21 $\mathrm{DAD}$ there was a reduction in moisture content of the sample in plants sprayed with both doses of glyphosate and in the control. At $28 \mathrm{DAD}$, the treatment with the highest glyphosate dose showed greater moisture removal, presenting around $60 \%$ in moisture content of the sample. Plants receiving paraquat, paraquat + diuron and glufosinate-ammonium remained with moisture content of the sample above $70 \%$, with no statistical difference between these herbicides. The treatment with the lowest glyphosate dose did not differ from the control and presented moisture content of the sample around $68 \%$.

In general, the regression analysis shows that all insecticide treatments had a stronger tendency in reducing leaf and panicle moisture contents than control (Figures 4A and 4C). However, only the treatments with glyphosate have stronger tendency in reducing culm moisture content (Figure 4B). It was possible to visibly notice the herbicidal action on plant leaves in all treatments when compared to the control (Figure 5). In addition, treatments with glyphosate and paraquat + diuron mixture resulted in plants whose culms had a whitish appearance, indicating moisture loss.

The differences in the tendencies of moisture reduction of different plant parts can be explained by the action mode of each herbicide. The rapid decrease of leaf moisture content of paraquat-based herbicides such as
Gramocil ${ }^{\circledR}$ (paraquat + diuron) and Gramoxone ${ }^{\circledR}$, is due to their action mode. Paraquat inhibit the electron flow of Photosystem I, and thus, the sunlight energy absorbed through Photosynthesis produces free radicals that rapidly damage organelle and cell membrane (plasmalema) (Sherwani et al., 2015). As a result, the symptoms of lesions appear very quickly. It also causes the leaves fall. Thus, after application of contact herbicides, with rapid response after desiccation, the most appropriate management would be to harvest the plants up to 14 days after application. Foloni et al. (2011) found that the water content of the castor bean plant canopy decreased from $79 \%$ to $61 \%$ at within 30 days after application of $1.2 \mathrm{~kg}$ a.i. ha- $\mathrm{ha}^{-1}$ paraquat. Despite glufosinate-ammonium increases the translocation of the product a little, it did not seem to increase desiccation of the culms. However, Pizolotto (2017) studied ammonium globule in pre-harvest canola desiccation and it was considered efficient. Although, these herbicides do not translocate within the plants, so they are not expected to act on culms.

Despite glyphosate has the effect on leaf moisture removal slower than paraquat, it causes higher culm moisture removal. The absorption of glyphosate by plants is slower and this product is translocated via phloem to the meristematic regions, where occurs the inhibition of tryptophan synthesis, which is a precursor of indolacetic acid hormone. Thus, cell expansion, apical dominance, and many other regulatory processes are affected. Symptoms include yellowing of the leaves and meristems, which progresses to necrosis and death in days or weeks. Treated plants die slowly, 7 to 14 days after application (Sherwani et al., 2015).

Our results corroborate those found by May et al. (2016) who evaluated the application of four doses of glyphosate $\left(0,720,1,440,2,160\right.$ and 2,880 g a.i. ha $\left.{ }^{-1}\right)$ in greenhouse biomass sorghum after 7, 14, 21 and 28 days after application. They verified that the herbicide was efficient in reducing the leaf moisture independent of the dose. Although, the authors considered that glyphosate was not effective because in comparison with the control the culm moisture reduction up to 28 days was low. However, in our experiment, both culm and leaf moisture contents were different from control, it shows the efficiency of glyphosate as desiccant.

Oliveira (2016) evaluated the natural drying of biomass sorghum in the field (without herbicide application) and reported that the moisture percentage was nearly $81 \%$ at 95 days after sowing (DAS), $78 \%$ at 125 DAS and $62 \%$ at 162 DAS. Considering that the desiccation in the present study was performed at $85 \mathrm{DAS}$, at the evaluation at 28 DAD and, therefore, at 113 DAS, the treatment with the highest glyphosate dose $\left(3.84 \mathrm{Kg}\right.$ a.i. ha $\left.{ }^{-1}\right)$ resulted in plants with approximately $60 \%$ moisture, therefore, 
inferring that desiccation with glyphosate can anticipate the harvest of sorghum biomass. Although the control in this work had around $68 \%$ moisture at 113 DAS, waiting in the field to reduce moisture up to $60 \%$ may compromise the quality of the raw material, especially in case of rain, severe wind blowing and attack by pests and pathogens, among other risks.

It is also noteworthy that the efficiency of the products may have been impaired because there was lodging of plants on the eighth day after desiccation due to rain and strong winds in the experimental area. Thus, plant overlap may have influenced moisture loss, making the drying process difficult. Bedding of sorghum plants is a recurring problem described by other authors (Silva et al., 2017; Oliveira, 2016). Thus, early harvesting can prevent this from occurring through less exposure to weather factors.

At 7 DAD the highest dose of glyphosate had the lowest value of superior calorific power (SCP), despite this value was not significantly different from control, paraquat and paraquat + diuron. However, at $14 \mathrm{DAD}$, the highest dose of glyphosate, paraquat + diuron and glufosinate-ammonium had the lowest value. At 21 DAD,

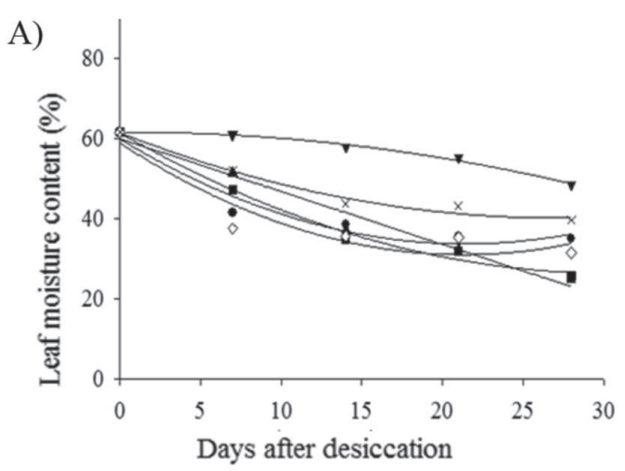

- Control (without desiccation) $=61.60+0.02 x-0.01 x^{2} r^{2}$ - Glyphosate $(1.92 \mathrm{~kg} / \mathrm{ha})=61.47-2.30 \mathrm{x}+0.03 \mathrm{x}^{2} \quad \mathrm{r}^{2}=0.99$

Glyphosate $(3.84 \mathrm{~kg} / \mathrm{ha})=60.01-1.31 \mathrm{x} \mathrm{r} \mathrm{r}^{2}=0.98$

- Paraquat $(0.4 \mathrm{~kg} / \mathrm{ha})=59.89-2.43 \mathrm{x}+0.05 \mathrm{x}^{2} \quad \mathrm{r}^{2}=0.97$

$\diamond$ Paraquat + diuron $(0.6+0.3 \mathrm{~kg} / \mathrm{ha})=58.88-2.61 \mathrm{x}+0.06$

$\times$ Glufosinate ammonium $(0.8 \mathrm{~kg} / \mathrm{ha})=61.46-1.56 \mathrm{x}+0.02$

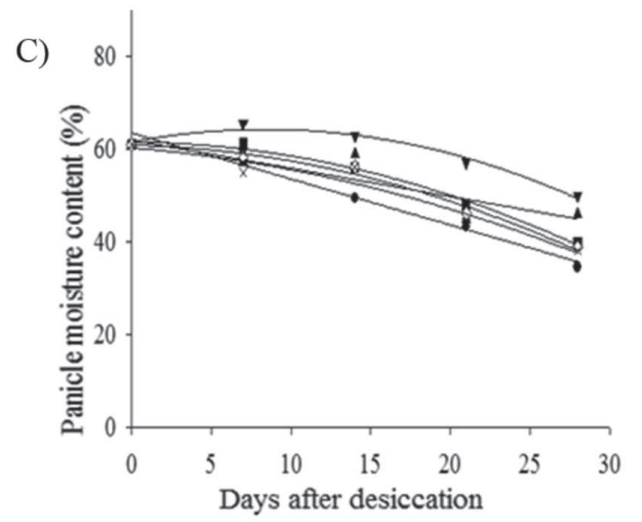

v Control (without desiccation $)=61.58+0.65 x-0.03 x^{2}$ $\mathrm{r}^{2}=0.98$

- Glyphosate $(1.92 \mathrm{~kg} / \mathrm{ha})=61.60-0.02 \mathrm{x}-0.02 \mathrm{x}^{2}$ $r^{2}=0.99$

- Glyphosate $(3.84 \mathrm{~kg} / \mathrm{ha})=61.96-0.60 \mathrm{x} \quad \mathrm{r}^{2}=0.87$

- Paraquat $(0.4 \mathrm{~kg} / \mathrm{ha})=63.49-0.99 \mathrm{x} \quad \mathrm{r}^{2}=0.98$

$\diamond$ Paraquat + diuron $(0.6+0.3 \mathrm{~kg} / \mathrm{ha})=60.94-0.084 \mathrm{x}-$ $0.02 \mathrm{x}^{2} \quad \mathrm{r}^{2}=0.99$

$\times \quad$ Glufosinate ammonium $(0.8 \mathrm{~kg} / \mathrm{ha})=60.34-0.28 \mathrm{x}-$ $0.01 x^{2} \quad r^{2}=0.96$
B)

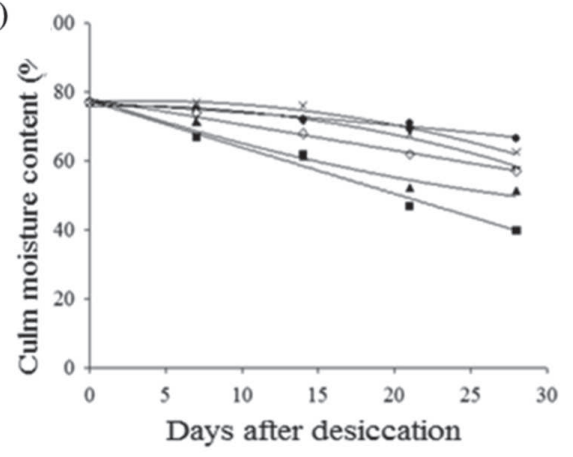

v Control (without desiccation) $=76.0+0.09 x-0.02 \mathrm{x}^{2}$ $r^{2}=0.97$

- Glyphosate $(1.92 \mathrm{~kg} / \mathrm{ha})=77.40-1.34 \mathrm{x} \quad \mathrm{r}^{2}=0.99$

A Glyphosate $(3.84 \mathrm{~kg} / \mathrm{ha})=78.17-1.46 \mathrm{x}+0.016 \mathrm{x}^{2}$ $\mathrm{r}^{2}=0.98$

- Paraquat $(0.4 \mathrm{~kg} / \mathrm{ha})=76.87-0.23 \mathrm{x}-0.004 \mathrm{x}^{2} \quad \mathrm{r}^{2}=0.98$

> Paraquat + diuron $(0.6+0.3 \mathrm{~kg} / \mathrm{ha})=78.00-0.74 \mathrm{x}$ $\mathrm{r}^{2}=0.99$

$\times$ Glufosinate ammonium $(0.8 \mathrm{~kg} / \mathrm{ha})=77.12+0.19 \mathrm{x}+$ $0.02 \mathrm{x}^{2} \quad \mathrm{r}^{2}=0.98$

D)

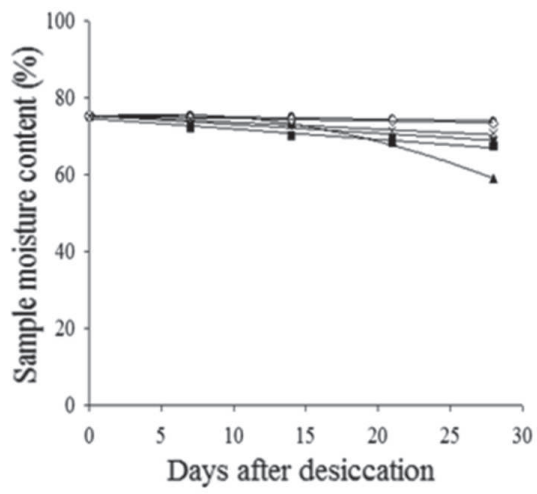

Control (without desiccation) $=75.41-0.22 \mathrm{x}$ $r^{2}=0.97$

- Glyphosate $(1.92 \mathrm{~kg} / \mathrm{ha})=74.68-0.27 \mathrm{x}$ $\mathrm{r}^{2}=0.98$

- Glyphosate $(3.84 \mathrm{~kg} / \mathrm{ha})=74.96+0.32 \mathrm{x}-0.03 \mathrm{x}^{2}$ $r^{2}=0.99$

- Paraquat $(0.4 \mathrm{~kg} / \mathrm{ha})=75.52-0.04 \times \quad \mathrm{r}^{2}=0.95$

$\diamond$ Paraquat + diuron $(0.6+0.3 \mathrm{~kg} / \mathrm{ha})=75.35-$ $0.06 \mathrm{x} \quad \mathrm{r}^{2}=0.98$

$\times$ Glufosinate ammonium $(0.8 \mathrm{~kg} / \mathrm{ha})=75.51-$ $0.18 \times r^{2}=0.98$

Figure 4: (A) Leaf moisture content (\%), (B) Culm moisture content (\%), (C) Panicle moisture content (\%) and (D) Sample moisture content (\%) of biomass sorghum plants before application (day 0) and at 7, 14, 21 and 28 days after spraying with glyphosate (1.92 $\mathrm{kg}$ a.i. ha ${ }^{-1}$ and $3.84 \mathrm{~kg}$ a.i. ha-1), paraquat, paraquat + diuron, glufosinate-ammonium and the control (without application). 

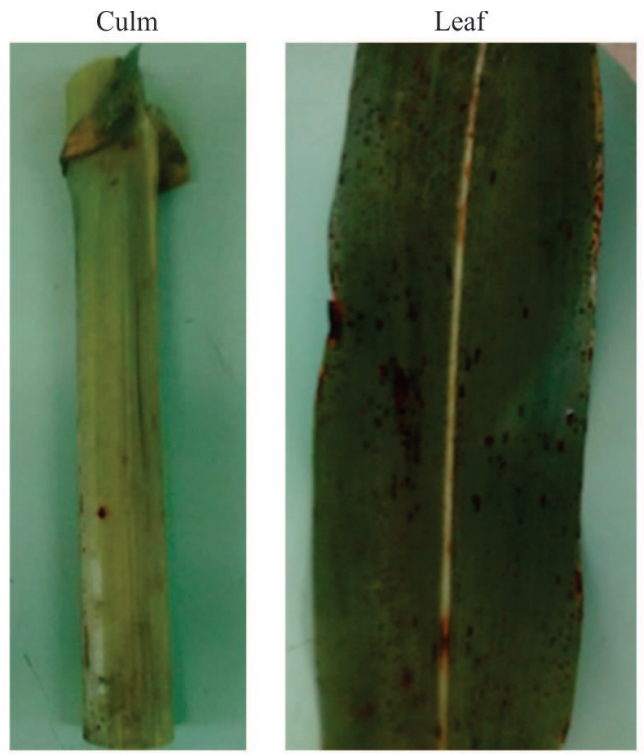

control (without application)

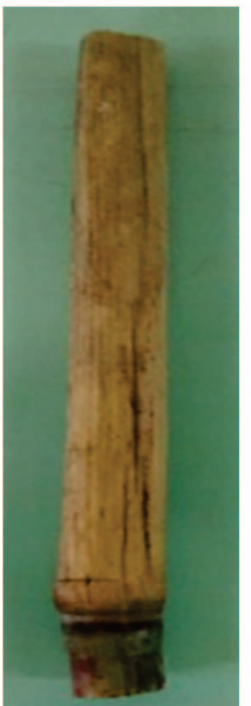

glyphosate (1.92 kg a.i. ha-1)
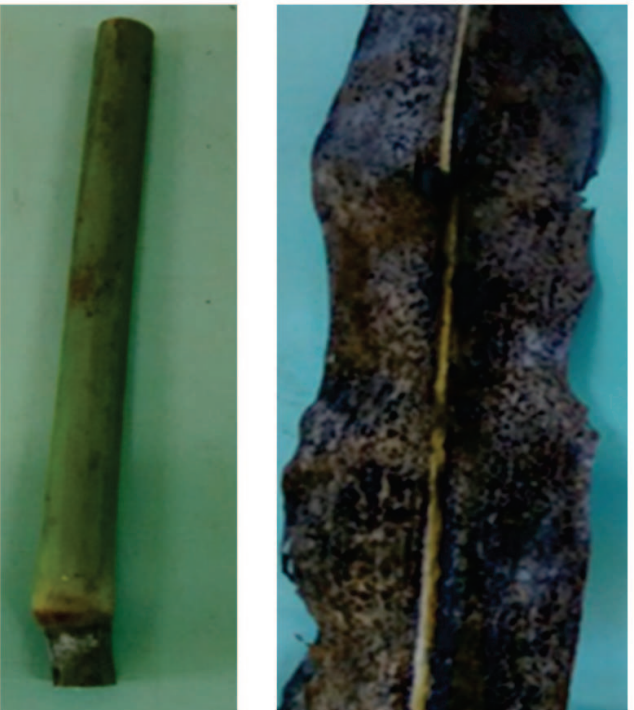

paraquat
Culm
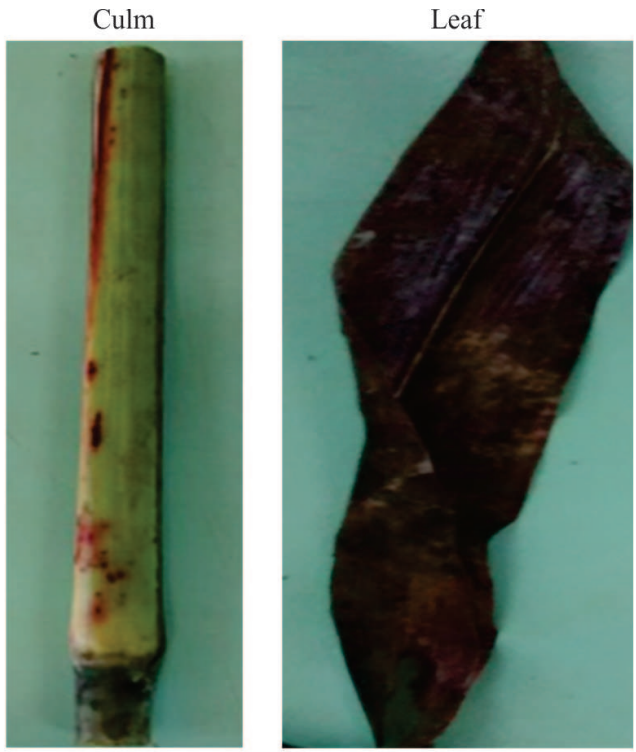

glufosinate-ammonium

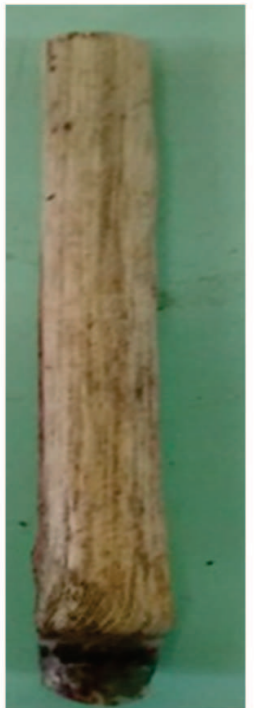

glyphosate (3.84 kg a.i. ha- $\left.{ }^{-1}\right)$

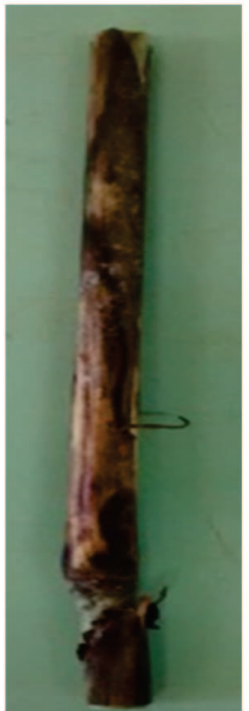

paraquat + diuron
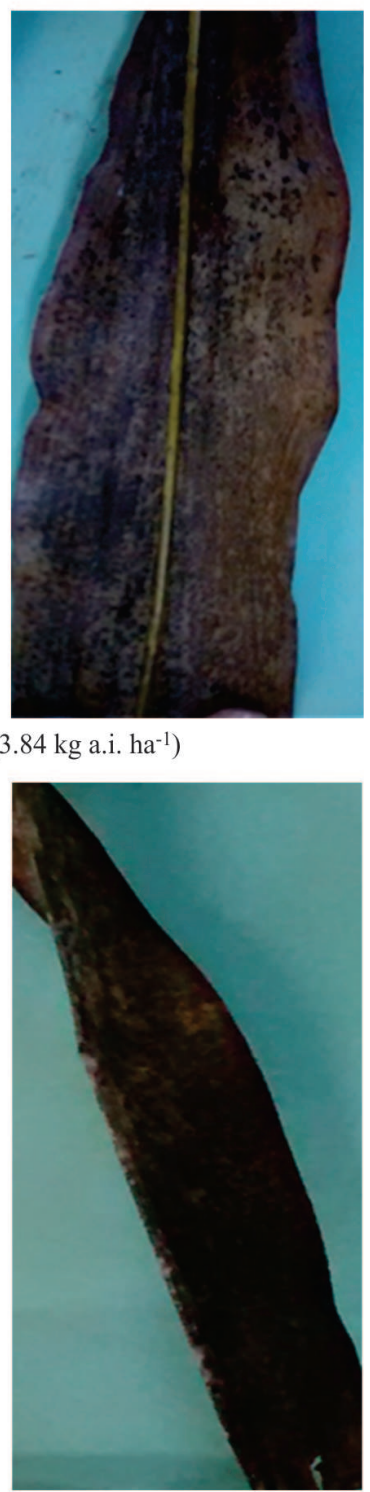

Figure 5: Visual effect of pre-harvest desiccation on biomass sorghum at 28 days after application, with leaf and culm details. 
the control had the SCP significant higher than all treatments. At $28 \mathrm{DAD}$ the control plants presented SCP of $4486 \mathrm{kcal} / \mathrm{kg}$, with no significant difference from glufosinate-ammonium. The lowest dose of glyphosate and paraquat had the lowest SCP values, on average 4320 $\mathrm{kcal} / \mathrm{kg}$. Although, studies in the literature describe the biomass sorghum SCP around $4.300 \mathrm{Kcal} / \mathrm{kg}$. Therefore, it cannot be stated that desiccation caused a reduction in plant SCP (Parrela et al., 2014; Pereira Filho \& Rodrigues, 2015). The results found even surpass the SCP of elephant grass, also considered a promising alternative energy source, with $4.130 \mathrm{kcal} / \mathrm{kg}$ (Saraiva \& Konig, 2013).

\section{CONCLUSIONS}

The herbicides glyphosate, paraquat, paraquat + diuron and glufosinate-ammonium reduce leaf and panicle moisture, however only glyphosate reduces moisture in the culm. Thus, the systemic product has a better effect on the moisture loss of the raw material as a whole and therefore has greater potential for use in pre-harvest desiccation. It is also emphasized that herbicides do not affect the calorific value of biomass sorghum. However, application of contact herbicides promotes defoliation and therefore harvesting should be done within 14 days of application to avoid loss.

\section{ACKNOWLEDGEMENTS, FINANCIAL SUPPORT AND FULL DISCLOSURE}

The authors would like to thank $\mathrm{CNPq}$ (Conselho Nacional de Desenvolvimento Científico e Tecnológico) and CAPES (Coordenação de Aperfeiçoamento de Pessoal de Nível Superior) for their financial support.

The authors declare there is no conflict of interests in carrying the research and publishing the manuscript.

\section{REFERENCES}

Alonso DM, Hakim SH, Zhou S, Won W, Hosseinaei O, Tao J \& Houtman CJ (2017) Increasing the revenue from lignocellulosic biomass: Maximizing feedstock utilization. Science advances, 3:01-07.

Alvim JC, Alvim FALS, Sales VHG, Sales PVG, Oliveira EM \& Costa ACR (2014) Biorrefinarias: Conceitos, classificação, matérias primas e produtos. Journal of Bioenergy and Food Science, 1:61-77.

Boletim meteorológico (2017) Estação Climatológica Principal de Viçosa. Available on: http://www.posmet.ufv.br/wp-content/ uploads/2015/04/Boletim-Meteorologico-201712.pdf. Accessed at: February $13^{\text {th }}, 2018$.

Colauzzi M, Serra P \& Amaducci S (2018) Variety earliness effect on field drying of biomass sorghum. Biomass and Bioenergy, 115:160-173.

Costa AG, Severino LS, Sofiatti V, Freitas JG, Gondim TM \& Cardoso GD (2018) Pre-harvest desiccation of castor crop using 2, 4 D and glyphosate. Industrial Crops and Products, 122:261-265.

Foloni JSS, Hirata ACS, Pereira DN, Carvalho MLM \& Casavechia D (2011) Dessecação química em pré-colheita da mamona. Revista Ceres, 58:665-669.
Galina NR, Luna CMR, Arce GL \& Ávila I (2018) Comparative study on combustion and oxy-fuel combustion environments using mixtures of coal with sugarcane bagasse and biomass sorghum bagasse by the thermogravimetric analysis. Journal of the Energy Institute, 92:741-754.

Guerriero G, Hausman JF, Strauss J, Ertan H \& Siddiqui KS (2016) Lignocellulosic biomass: biosynthesis, degradation, and industrial utilization. Engineering in Life Sciences, 16:01-16.

Krenchinsk FH, Cesco VJS, Rodrigues DM, Pereira VGC, Albrecht AJP \& Albrecht LP (2017) Yield and physiological quality of wheat seeds after desiccation with different herbicides. Journal of Seed Science, 39:254-261.

Liu F, Chen G, Yan B, Ma W, Cheng Z \& Hou LA (2017) Exergy analysis of a new lignocellulosic biomass-based polygeneration system. Energy, 140:1087-1095.

May A, Parrela RDC, Parrela N, Schaffert RE, Castro L \& Assis RD (2015) Sorgo Biomassa para a Cogeração de Energia. Sete Lagoas, Embrapa. 7p. (Circular Técnica, 211).

May A, Silva Viana R, Santos MDS \& Silva EHFM (2016) Aplicação de glyphosate na dessecação do sorgo biomassa. Revista Brasileira de Herbicidas, 15:362-370.

Moura EG, Aguiar CFA, Piedade AR \& Rousseau GX (2015) Contribution of legume tree residues and macrofauna to the improvement of abiotic soil properties in the eastern Amazon. Applied Soil Ecology, 86:91-99.

Oliveira NAB (2016) O uso do sorgo biomassa para cogeração: aspectos técnicos e econômicos. Dissertação de Mestrado. Fundação Getúlio Vargas, São Paulo. 94p.

Parreira MC, Lemos LB, Portugal J \& Costa Alves PL (2015) Effects of desiccation with glyphosate on two common bean cultivars: physiology and cooking quality of the harvested product. Australian Journal of Crop Science, 9:925.

Parrela RAC, Menezes CB, Rodrigues JAS, Tardin FD, Parrella NNLD \& Schaffert RE (2014) Cultivares. In: Borém A, Pimentel LD \& Parrella RAC (Eds.) Sorgo: do Plantio à Colheita. Viçosa, UFV. p.169-187.

Pereira Filho IA \& Rodrigues JAS (2015) Sorgo: o produtor pergunta, a Embrapa responde. Brasília, Embrapa. 327 p.

Pinto CC, Oliveira CO, Américo GH, Vazquez GH \& Lazarini E (2016) Efeito da dose e da época de aplicação do glifosato na produção e na qualidade da soja RR. Revista de Ciências Agrárias, 39:310-317.

Pizolotto CA, Boller W, Lângaro NC \& Tomm GO (2017) Manejo da colheita de canola com dessecação e corte-enleiramento combinados a adesionante. Acta Iguazu, 6:81-97.

Saraiva VM \& Konig A (2013) Produtividade do capim-elefanteroxo irrigado com efluente doméstico tratado no semiárido potiguar e suas utilidades. Holos, 1:28-46.

Sherwani SI, Arif IA \& Khan HA (2015) Modes of action of different classes of herbicides. In: Price A, Kelton J \& Sarunaite L (Eds.) Herbicides, Physiology of Action, and Safety. Croácia, InTech Publishers. p.165-186.

Silva PV, Ronchi Filho PCC, Santos PHV, Moraes N, Monquero PA, Tronquine S \& Buzzato ACB (2017) Dessecação da cultura do feijão através de herbicidas visando à antecipação de colheita. Ensaios Pioneiros, 1:14-25.

Teixeira TPM (2017) Estudo da maturação e ponto de colheita em materiais de sorgo destinados à bioenergia. Dissertação de mestrado. Universidade Federal de Viçosa, Viçosa. 84p.

Zhang M \& Van Veldhuizen R (2016) Varieties and Pre Harvesting Treatment for Growing Polish Canola (Brassica rapa L.) in Interior Alaska. Universal Journal of Agricultural Research, 4:211-216. 